\title{
POTENSI NILAI MANFAAT EKONOMI DAN KESEDIAAN PETANI MEMBAYAR JASA LAYANAN IRIGASI CIPANGARANGAN
}

\section{THE POTENTIAL VALUE OF ECONOMIC BENEFIT AND FARMERS WILLINGNESS TO PAY CIPANGARANGAN IRRIGATION SERVICES}

\author{
Bintang Maulana Gentzora ${ }^{1}$, Trisna Insan Noor $^{2}$, Eka Purna Yudha ${ }^{3}$ \\ Program Studi Magister Ekonomi Pertanian Fakultas Pertanian Universitas Padjadjaran \\ *E-mail: gentzora88@gmail.com
}

(Diterima 03-06-2021; Disetujui 05-07-2021)

\begin{abstract}
ABSTRAK
Penelitian ini dilatarbelakangi oleh adanya ketimpangan ketersediaan dengan kebutuhan air irigasi Cipangarangan. Petani pemakai air mengusulkan merevitalisasi jaringan irigasi. Berdasarkan latar belakang tersebut, tujuan penelitian ini adalah a) melakukan estimasi nilai manfaat ekonomi dari revitalisasi irigasi; b) analisis kemampuan (ATP) dan keinginan membayar WTP) petani atas jasa layanan irigasi.Metode yang digunakan adalah mixed method research dengan data primer dan sekunder. Penentuan responden dilakukan dengan proportional random sampling. Kesimpulan hasil penelitian : a) Revitalisasi irigasi Cipangarangan diprediksi dapat meningkatkan nilai manfaat ekonomi $\mathrm{Rp}$ 10.934.091.000/tahun, dari peningkatan nilai bersih pendapatan usahatani padi $\mathrm{Rp}$ 7.707.231.000 dan serapan tenaga kerja setara dengan Rp 3.226.860.000/tahun. b) Rata-rata ATP untuk jasa layanan irigasi relative lebih kecil (Rp 38.749) jika dibandingkan dengan rata-rata WTP (Rp 71.195). Kondisi ini menunjukan jangkauan kemampuan petani untuk membayar jasa layanan irigasi lebih kecil dari keinginannya untuk membayar (ATP $<$ WTP). Kondisi seperti ini menggambarkan keberanian petani untuk membayar jasa layanan irigasi melebihi jangkauan kemampuannya, utilitas jasa irigasi relatif lebih tinggi daripada pendapatan pengguna jasa. Kondisi seperti ini disebut Captive riders.
\end{abstract}

Kata Kunci: ATP, WTP, revitalisasi irigasi, nilai manfaat ekonomi

\section{ABSTRACT}

This research is motivated by the inequality of availability with the needs of Cipangarangan irrigation water. Farmers using water are proposing to revitalize the irrigation. Based on this background, the objectives of this study are a) to estimate the value of economic benefits from irrigation revitalization; b) analysis of ability (ATP) and willingness to pay WTP) of farmers for irrigation services, and c) knowing ATP and WTP of irrigation services with farmer characteristics. The method used is a mixed method research with primary and secondary data. Respondents were determined using proportional random sampling. The conclusions of the research results: a) Cipangarangan irrigation revitalization is predicted to increase the economic benefit value of Rp. 10,934,091,000 / year, originating from an increase in the net value of rice farming income of $R p$. 7,707,231,000 and labor absorption equivalent to $R p$. 3,226,860,000 / year. b) The average ATP for irrigation services is relatively smaller (Rp. 38,749) when compared to the average WTP (Rp. 71,195). This condition shows that the range of farmers' ability to pay for irrigation services is smaller than their willingness to pay $(A T P<W T P)$. Conditions like this illustrate the courage of farmers to pay for irrigation services beyond their reach, the utility of irrigation services is relatively higher than the income of service users. This condition is called Captive riders.

Keywords: ATP, WTP, irrigation revitalization, economic benefit value 


\section{PENDAHULUAN}

Cipangarangan adalah sungai yang berasal dari 5 (lima) titik mata air yang terletak di perbukitan hutan lindung kaki Gunung Galunggung. Secara administratif termasuk wilayah Kecamatan Cigalontang Kabupaten Tasikmalaya. Di bagian hulu sungai, dibuat bendungan sederhana atas inisiatif dan swadaya masyarakat dengan maksud agar air mengalir masuk ke jaringan irigasi. Saluran irigasi yang dibuat masyarakat menyusur perbukitan, berupa saluran gantung, sehingga rawan longsor yang berakibat putusnya aliran air karena tumpah ke bagian bawah bukit. Risiko lainnya, saluran air berisiko tertimbun longsoran tebing yang menjadi sisi lain dari saluran irigasi.

Kurang lebih 600 hektar lahan sawah dapat diairi dengan sumber air Cipangarangan melalui jaringan irigasi sederhana yang dibangun secara swadaya. Selain dimanfaatkan penduduk untuk pengairan lahan pertanian, juga dimanfaatkan untuk keperluan budidaya perikanan air tawar. Lebih dari itu, tidak kurang dari 950 kepala keluarga di tiga desa selama ini memanfaatkan sebagian dari sumber air tersebut untuk keperluan MCK dan keperluan domestik lainnya (Dinas SDA Provinsi Jawa Barat, 2017).
Dalam kurun waktu dua dasawarsa terakhir ini, debit air Cipangarangan semakin menyusut, hal ini berdampak pada ketersediaan air pada saluran irigasi sepanjang tahun relatif lebih rendah dari kebutuhannya. Ketersediaan air berada pada kisaran (30-580) 1t/detik. Apabila dibandingkan dengan kebutuhan maksimalnya $1012 \mathrm{lt} / \mathrm{dt}$, terdapat ketimpangan yang cukup besar. Ketrsediaan air sekarang ini hanya mampu memenuhi kebutuhan (75-80)\% (Dinas SDA Provinsi Jawa Barat, 2017).

$$
\text { Warga Desa Cigalontang, }
$$

Puspamukti, dan Pusparaja berkeinginan meningkatkan kapasitas irigasi Cipangarangan. Mereka telah menyampaikan usulan revitalisasi jaringan irigasi Cipangarangan kepada pemerintah daerah Kabupaten Tasikmalaya. Substansi usulan masyarakat Desa Cigalontang, Puspamukti, dan Pusparaja pemakai air tentang revitalisasi irigasi Cipangarangan meliputi dua hal, yaitu: a) pembangunan bendungan dan b) meningkatkan status dari jaringan irigasi sederhana Cipangarangan menjadi jaringan irigasi teknis. Dengan revitalisasi jaringan irigasi, penggunaan sumber daya air diharapkan akan lebih teratur, efisien dan berkesinambungan. 
Berkaitan dengan adanya keinginan dari petani untuk merevitalisasi jaringan irigasi Cipangarangan, timbul pertanyaan, adakah kesediaan membayar dari petani pemakai air atas jasa jaringan irigasi yang direvitalisasi tersebut. Berapa besar kemampuan membayar (ability to pay, ATP) petani berdasarkan besarnya volume air yang digunakan untuk usahataninya. Disamping itu dipertanyakan pula berapa besar keinginan membayar (willingness to pay, $W T P)$ petani terhadap jasa layanan jaringan irigasi yang dinikmatinya. Perhitungan besarnya ATP berdasarkan pendapatan yang diterima oleh responden, sedangkan basis perhitungan WTP berbasiskan pada kepuasan responden. Mana yang lebih besar diantara ability to pay dibandingkan dengan willingness to pay, merupakan salah satu fokus kajian penelitian ini.

Penelitian dilaksanakan dengan tujuan untuk menganalisis besarnya potensi tambahan nilai manfaat ekonomi yang akan diperoleh jika dilaksanakan revitalisasi jaringan irigasi, serta kemampuan membayar (Ability to pay, ATP) dan keinginan membayar (willingness to pay, WTP) petani pemanfaat air atas jasa layanan irigasi.

\section{METODE PENELITIAN}

Penelitian ini memadukan pendekatan kualitatif dan kuantitatif, sehingga metode yang digunakan dalam penelitian ini adalah mixed method research dengan dominasi desain kuantitatif. Creswell John (2010) dan Sugiyono (2017) pada intinya menyatakan bahwa Mix Method Research adalah penelitian yang memadukan penelitian kualitatif dan kuantitatif. Penentuan responden dilakukan dengan proportional random sampling. Sementara data yang digunakan adalah data primer dan data sekunder. Disamping responden petani pemakai air digunakan key informan yang terdiri atas tokoh masyarakat dan perangkat desa untuk keperluan deep interview.

Terdapat tiga konsep yang menjadi pokok bahasan penelitian ini, yaitu: Nilai Manfaat Ekonomi (NME) dan Kesediaan Petani Membayar, yang dijabarkan menjadi kemampuan membayar (ability to pay, ATP) dan keinginan membayar (willingness to pay, WTP).

Nilai manfaat Ekonomi (NME) dalam konteks penelitian ini adalah nilai ekonomi yang secara langsung dinikmati oleh masyarakat yang berdomisili pada daerah irigasi, yaitu petani pengambil manfaat air dan buruh tani yang membantu mengelola usahatani. NME 


\section{POTENSI NILAI MANFAAT EKONOMI DAN KESEDIAAN PETANI MEMBAYAR JASA LAYANAN \\ IRIGASI CIPANGARANGAN \\ Bintang Maulana Gentzora, Trisna Insan Noor, Eka Purna Yudha}

pemanfaatan irigasi dari usahatani padi dan curahan tenaga kerja untuk usahatani padi, dihitung menggunakan format

Tabel 1 .

Tabel 1 Variabel dan Parameter untuk Menghitung Nilai Manfaat Ekonomi Usahatani Padi

\begin{tabular}{llll}
\hline \multicolumn{1}{c}{ Variabel } & \multicolumn{1}{c}{ Parameter } & Skala Ukur \\
\hline Produksi padi per tahun & a. & Luas baku lahan (Ha) & Rasio \\
& b. & Produktivitas usahatani /Ha & Rasio \\
& c. & Indeks Pertanaman (IP) & Rasio \\
& d. & Harga/kg padi (Rp) & Rasio \\
Nilai Produksi Padi & & & (a) x (b) x (c) x (d) \\
Curahan tenaga kerja & a. & Curahan HKP/Ha sawah & Rasio \\
Buruh Tani & b. Curahan HKW/Ha sawah & Rasio \\
& c. Upah/HKP (Rp) & Rasio \\
Nilai Curahan Tenaga Kerja Pria & d. Upah/HKW (Rp) & Rasio \\
Nilai Curahan Tenaga Kerja Wanita & & (a) $\mathrm{x}(\mathrm{c})$ & (a) x (c) \\
\hline
\end{tabular}

Untuk menghitung NME

Tabel 1. NME dari penggunaan air untuk pemanfaatan irigasi dari budidaya mandi cuci dan kakus dihitung perikanan air tawar (kolam), menggunakan format Tabel 2.

menggunakan format yang sama dengan

Tabel 2. Variabel dan Parameter untuk Menghitung Nilai Manfaat Ekonomi dari Penggunaan Air untuk Keperluan Domestik

\begin{tabular}{llll}
\hline \multicolumn{1}{c}{ Variabel } & & \multicolumn{1}{c}{ Parameter } & Skala Ukur \\
\hline Nilai Pemanfaatan air untuk & a. & Jumlah penduduk pemanfaat air & Rasio \\
keperluan domestik & b. & Kebutuhan air perkapita pedesaan* & Rasio \\
& c. & Harga/tarif air standar PDAM & Rasio \\
\hline Total Nilai Manfaat Air & & & (a) x (b) x (c)
\end{tabular}

*) Standar kebutuhan air penduduk di pedesaan menurut Permen PU Nomor 14/2010 adalah 60 lt/hari per orang

\section{Kemampuan Membayar (ATP)}

Ability to pay (ATP) didefinisikan sebagai batas maksimum kemampuan dari penghasilan seseorang yang dialokasikan untuk membayar jasa yang diterimanya. Dalam hal ini batas maksimum kemampuan pemakai air untuk membayar iuran jasa layanan irigasi dari hasil usahatani yang pengairannya dari jasa layanan irigasi tersebut. ATP dihitung menggunakan metode household budget seperti yang pernah digunakan penelitian (Permata, 2012), dengan rumus berikut:
$A T P=\frac{I x(\% I)}{D}$

Keterangan:

ATP=Ability To Pay (Kemampuan/daya beli petani) untuk membayar, dinyatakan dalam satuan rupiah (Rp).

$\mathrm{I}=$ Income $\quad($ Pendapatan $/$ keuntungan petani dari usahatani yang menggunakan sumber air irigasi Cipangarangan), dinyatakan dalam satuan rupiah (Rp).

$\% \mathrm{I}=$ Proporsi pendapatan untuk membayar jasa layanan irigasi, dinyatakan dalam persentase (\%)

$\mathrm{D}=$ Kuantitas air yang digunakan petani dalam usahataninya dinyatakan dalam satuan $\mathrm{m}^{3}$ 


\section{Keinginan Membayar (WTP)}

Willingness to pay (WTP) adalah kesediaan konsumen membayar untuk imbalan jasa yang diperolehnya. Lebih spesifik dalam penelitian ini diartikan sebagai kesediaan petani pemakai air membayar jasa layanan irigasi, yang besaran nominalnya didasarkan atas dasar persepsi utilitas petani pemakai air terhadap jasa layanan irigasi. Terdapat beberapa cara untuk menghitung WTP. Pada penelitian ini digunakan cara dengan pendekatan Contingent Valuation Method (CVM) berikut:

1) Pertama membuat pasar hipotetik, yaitu dengan cara memberikan informasi kepada responden mengenai jasa layanan irigasi pasca revitalisasi irigasi yang akan dinikmati oleh responden.

2) Kedua menawarkan nilai lelang secara berjenjang, atau biasa disebut bidding games.

3) Nilai lelang dikonversi ke dalam satuan luas bata/tumbak. Besarnya iuran $10 \mathrm{~kg} / \mathrm{ha}$ setara dengan $\mathrm{Rp}$. 64,29 /bata; $15 \mathrm{~kg} / \mathrm{ha}$ setara dengan Rp. 96,43/bata; 20 kg/ha setara dengan Rp. 128,57 /bata; 25 kg/ha setara dengan Rp. 160,71/bata dan 30 kg/ha setara dengan Rp. 192,86/bata.

4) Menghitung WTP (rata-rata)

Menghitung WTP rata-rata digunakan rumus sebagai berikut:

$$
E W T P=\frac{\hat{\mathrm{a}}_{i=1}^{n} \cdot W i}{n}
$$

Keterangan :

EWTP $=$ WTP rata-rata

$W i=$ WTP untuk responden ke-i

$n$ = banyaknya responden

$i \quad=$ Responden yang ke $\mathrm{i}$

5) Menghitung WTP agregat

WTP agregat dihitung dari nilai WTP rata-rata dikonversi dengan populasi Rumus WTP total yang digunakan adalah:

TWTP = EWTPi.N

Keterangan:

TWTP $=$ WTP total

$\mathrm{EWTP}=\mathrm{WTP}$ rata-rata

$\mathrm{N}=$ populasi

6) Estimasi kurva WTP

Kurva WTP menggambarkan proporsi jumlah responden pada setiap tingkatan harga yang disanggupi responden. Kurva WTP menggambarkan tingkat harga yang ditawarkan (WTP) yang bersedia dibayarkan dengan jumlah responden yang bersedia membayar pada tingkat WTP tersebut.

Dengan rumusan tersebut di atas, maka dapat dihitung keinginan membayar dari pengambil manfaat atas dilakukannya revitalisasi jaringan irigasi. Terdapat tiga kemungkinan hasil 
perhitungan WTP dan ATP sebagai berikut:

- $\quad$ ATP > WTP, jangkauan kemampuan petani untuk membayar lebih besar dari keinginannya membayar jasa layanan irigasi. Utilitas jasa layanan irigasi relatif lebih rendah dibandingkan dengan penghasilan petani. Petani sebagai pengguna jasa dalam posisi Choiced riders.

- ATP $<$ WTP, jangkauan kemampuan petani untuk membayar lebih kecil dari keinginan untuk membayar jasa layanan irigasi. Utilitas jasa irigasi relatif lebih tinggi daripada penghasilan pengguna jasa. Kondisi seperti ini disebut Captive riders.

- $\mathrm{ATP}=\mathrm{WTP}$, jangkauan kemampuan membayar setara dengan keinginan untuk membayar. Kondisi ini terjadi saat keseimbangan antara utilitas jasa sama atau sebanding dengan penghasilan petani.

\section{HASIL DAN PEMBAHASAN}

\section{Estimasi Nilai Manfaat Ekonomi Jasa Layanan Irigasi}

Jasa layanan irigasi yang utama adalah menyediakan sumberdaya air untuk mengairi lahan pertanian. Sumberdaya air adalah input pada proses produksi, usahatani. Maka nilai manfaat ekonomi jasa layanan irigasi dalam konteks penelitian ini adalah nilai ekonomi dari ouput atas penggunaan sumberdaya air dari irigasi Cipangarangan. Hasil analisis estimasi besarnya tambahan nilai manfaat ekonomi jasa layanan irigasi sebagai output revitalisasi Rp 10.934.091.000, dihitung melalui pendekatan empat komponen, yaitu: a) nilai output dari usahatani padi b) nilai output dari usaha perikanan, c) upah buruh tani pada usahatani padi dan perikanan dan, d) nilai ekonomi penggunaan air bersih untuk keperluan domestik.

Tabel 3. Rekapitulasi Estimasi Nilai Manfaat Ekonomi

\begin{tabular}{llrrr}
\hline No & \multicolumn{1}{c}{$\begin{array}{c}\text { Komponen } \\
\text { NME }\end{array}$} & $\begin{array}{c}\text { Aktual } \\
(\mathbf{R p})\end{array}$ & $\begin{array}{c}\text { Estimasi Pasca } \\
\text { Revitalisasi (Rp) }\end{array}$ & $\begin{array}{c}\text { Tambahan NME } \\
(\text { Rp) }\end{array}$ \\
\hline 1 & Produksi Padi & 18.630 .000 .000 & 26.337 .231 .000 & 7.707 .231 .000 \\
2 & Upah Buruh Tani & 7.800 .000 .000 & 11.026 .860 .000 & 3.226 .860 .000 \\
3 & Budidaya Perikanan & 128.250 .000 & 128.250 .000 & - \\
4 & Manfaat Air untuk MCK & 102.984 .750 & 102.984 .750 & - \\
\hline & NME Total & & & 10.934 .091 .000 \\
\hline
\end{tabular}

\section{Estimasi Nilai Manfaat Ekonomi dari Usahatani Padi}

Nilai manfaat ekonomi irigasi atas pemanfaatan air untuk usahatani padi, dihitung dari nilai produksi padi dan besarnya upah curahan tenaga kerja buruh tani yang bekerja pada usahatani padi tersebut. 
Nilai Produksi Usahatani Padi

Komponen nilai output usahatani padi terdiri atas beberapa variabel, yaitu: Luas baku lahan usahatani; Indeks pertanaman dan Luas Tanam; produktivitas lahan; Volume produksi. Untuk lebih memudahkan memahami uraian berikut ini disajikan Tabel 4.

Tabel 4. Resume Estimasi Nilai Produksi Pasca Revitalisasi Irigasi

\begin{tabular}{llrrr}
\hline Komponen & Satuan & $\begin{array}{r}\text { Kondisi } \\
\text { Aktual }\end{array}$ & $\begin{array}{r}\text { Prediksi Pasca } \\
\text { Revitalisasi }\end{array}$ & Kenaikan \\
\hline Luas Baku & Ha & 600,00 & 706,85 & 106,85 \\
IP & & 2,50 & 3 & 0,50 \\
Luas Tanam & $\mathrm{Ha} /$ th & $1.500,00$ & $2.120,55$ & 620,55 \\
Produktivitas & Ton/ha & 6,00 & 6 & - \\
Volume Produksi* & ton & $9.000,00$ & $12.723,30$ & $3.723,30$ \\
Harga & Rp/ton & $4.500 .000,00$ & 4.500 .000 & - \\
Nilai Produksi & Rp /tahun & 40.500 .000 .000 & 57.254 .850 .000 & 16.754 .850 .000 \\
\hline
\end{tabular}

Keterangan: *Luas tanam diasumsikan sama dengan luas panen, maka volume produksi dihitung dari luas tanam. Dalam konteks penelitian ini asumsi tersebut dianggap lebih relavan, dibandingkan dengan menggunakan data luas panen. Data luas panen lebih melihat luasan panen pada periode tertentu, tidak melihat dari luas tanam berapa luas panen tersebut terjadi.

\section{Luas Baku Lahan.}

Berdasarkan data monografi desa dan Rencana Definitif Kelompok (RDKK) luas lahan sawah di lokasi penelitian \pm 706,85 Ha, tersebar di tiga desa, yaitu Desa Cigalontang 281,83 Ha, Desa Puspamukti 278,97 Ha dan Desa Pusparaja 146,05 Ha. Lahan sawah yang dapat diairi dengan irigasi Cipangarangan hanya \pm 600 Ha. Hal ini berkaitan dengan ketersediaan debit air irigasi Cipangarangan sekarang ini 227 1t/detik, padahal kebutuhannya rata-rata mencapai 448 liter/detik. Keadaan ini merupakan salah satu dasar usulan revitalisasi irigasi, dengan harapan debit air akan meningkat dan dapat memenuhi seluruh kebutuhan.
3. Indeks Pertanaman dan Luas Tanam.

Revitalisasi irigasi diprediksi akan menambah ketersediaan air, sehingga luas lahan sawah yang dapat diairi bertambah, dari $600 \mathrm{Ha}$ menjadi 706,85 Ha. Ada kenaikan luas lahan yang dapat terairi sebesar 106,85 Ha. Peningkatan debit air sebagai output revitalisasi, juga akan meningkatkan indeks pertanaman, lahan yang semula hanya dapat ditanami hanya satu dan atau dua kali musim tanam dalam satu tahun, pasca revitalisasi diharapkan akan meningkat menjadi ratarata tiga kali tanam dalam satu tahun. Secara keseluruhan indeks pertanaman diprediksi akan meningkat dari rata-rata IP250 menjadi IP300. Luas tanam padi pasca revitalisasi, diprediksi akan meningkat dari $\pm 1.500 \mathrm{Ha}$ per tahun 
menjadi $\pm 2.120,55 \mathrm{Ha} /$ tahun. Ada kenaikan luas tanam 620,55 Ha per tahun.

4. Produktivitas Lahan.

Produktivitas rata-rata usahatani padi pada lahan sawah di lokasi penelitian, dikonfirmasi dengan data yang bersumber dari Balai Penyuluhan Pertanian (BPP) Cigalontang, berkisar antara 5,5-6,5 ton gabah kering pungut (GKP) per Ha permusim. Revitalisasi jaringan irigasi diasumsikan tidak akan signifikan menaikan produktivitas, sehingga produktivitas lahan sawah diprediksi akan tetap sebelum maupun pasca revitalisasi jaringan irigasi. Untuk keperluan estimasi dalam penelitian ini diambil angka produktivitas usahatani padi rata-rata dari $(5,5-6,5)$ ton/ha GKP menjadi 6 ton/ha per musim tanam.

5. Volume Produksi.

Volume produksi usahatani padi per tahun dihitung dari estimasi luas tanam dan produktivitas sebagaimana nilainya masing-masing telah diuraikan di atas. Produksi padi pada kondisi aktual, dari luas tanam $1.500 \mathrm{Ha} /$ tahun dan produktivitas 6 ton/Ha adalah 9.000 ton GKP/tahun. Dengan dilakukan revitalisasi luas tanam menjadi 2.120,55 Ha, produktivitas diasumsikan tetap 6 ton/Ha maka volume produksi padi diprediksi akan meningkat menjadi
12.723,30 ton GKP/ tahun. Ada kenaikan volume produksi sebesar 3.723,30 ton GKP.

6. Nilai Produksi Padi.

Nilai produksi padi tidak dihitung berdasarkan standar harga dasar (floor price) maupun harga atap (ceiling price), namun menggunakan harga pasar. Harga pasar gabah kering pungut saat dilakukan penelitian adalah $\mathrm{Rp} 4.500 / \mathrm{kg}$, maka apabila dinilai dengan uang, produksi padi dalam kondisi aktual sebanyak 9.000 ton setara dengan Rp 40.500.000.000. Sementara nilai produksi padi pasca revitalisasi $12.723,30$ ton GKP setara dengan $\mathrm{Rp}$ 57.254.850.000. Ada kenaikan nilai produksi padi $\mathrm{Rp}$ 16.754.850.000 pasca dilakukan revitalisasi.

7. Pendapatan Usahatani.

Nilai manfaat ekonomi yang telah diuraikan adalah nilai ekonomi volume produksi padi. Untuk menjadi nilai pendapatan "yang dibawa ke rumah" keluarga petani masih harus dikurangi dengan biaya produksi usahatani. Revenue-Cost Ratio $(R / C)$ rata-rata usahatani padi sawah berdasarkan hasil identifikasi terhadap seluruh responden berkisar antara 1,25-1,8, dengan rata-rata 1,46, maka proporsi besarnya pendapatan usahatani rata-rata adalah 0,46 . Rincian perhitungan estimasi pendapatan 
usahatani rata-rata dapat dilihat dalam

Tabel 5.

Tabel 5. Estimasi Pendapatan dari Nilai Produksi Padi

\begin{tabular}{clrrr}
\hline No & \multicolumn{1}{c}{ Uraian } & \multicolumn{1}{c}{ Aktual } & Pasca Revitalisasi & \multicolumn{1}{c}{ Selisih } \\
\hline 1 & Penerimaan (Rp) & 40.500 .000 .000 & 57.254 .850 .000 & 16.754 .850 .000 \\
2 & R/C rata-rata & 1,46 & 1,46 & \\
3 & \% Pendapatan & 0,46 & 0,46 & \\
4 & Pendapatan (Rp) & 18.630 .000 .000 & 26.337 .231 .000 & 7.707 .231 .000 \\
\hline
\end{tabular}

Laba usahatani padi, pendapatan keluarga petani diprediksi meningkat setelah dilakukan revitalisasi irigasi. Laba petani aktual Rp 18.630.000.000 per tahun, akan meningkat menjadi $\mathrm{Rp}$ 26.337.231.000. Penambahan pendapatan agregat (bersih) dari usahatani padi pasca revitalisasi sebesar Rp 7.707.231.000 per tahun.

\section{Nilai Curahan Tenaga Kerja Buruh Tani}

Nilai manfaat ekonomi dari curahan tenaga buruh tani untuk mengelola usahatani padi, dihitung melalui pendekatan jumlah curahan tenaga buruh tani persatuan luas usahatani, besarnya upah per hari. Jumlah agregat upah buruh tani diestimasi dari data luas tanam usahatani padi.

Tenaga kerja untuk mengelola usaha tani dapat dibedakan, berdasarkan sumbernya, yaitu tenaga kerja keluarga dan tenaga kerja dari luar keluarga. Tenaga kerja luar keluarga adalah tenaga kerja buruh tani yang diberi upah harian. Tenaga kerja keluarga adalah tenaga kerja yang bersumber dari anggota keluarga petani. Tenaga kerja keluarga dan luar keluarga dalam penelitian ini diperhitungkan sebagai pengeluaran biaya usahatani. Berdasarkan jenis dan sifat pekerjaannya dalam pengelolaan usahatani ada pekerjaan yang lebih efisien menggunakan tenaga kerja pria, namun untuk pekerjaan tertentu lebih baik menggunakan tenaga kerja wanita.

Zahasfana dkk (2017) menyatakan curahan tenaga kerja untuk mengelola usahatani padi bersumber dari luar keluarga $74,47 \mathrm{HKP} / \mathrm{Ha}$ dan tenaga kerja dalam keluarga 13,68 HKP/Ha. Sementara Kawengian dkk (2019) menyatakan jumlah curahan tenaga kerja pria untuk mengelola lahan padi sawah dalam satu musim adalah 78,375 HKP dan curahan tenaga kerja wanita 39,375 HKW. Berdasarkan hasil identifikasi di lapangan rata-rata curahan tenaga kerja untuk mengolah lahan sawah di lokasi penelitian terdiri atas $80 \mathrm{HKP}$ dan 40 HKW per hektar per musim.

Lazimnya jam kerja dalam mengelola usahatani padi di lokasi penelitian berkisar antara jam 7.00 pagi 
sampai dengan jam 12.00 siang, menjelang waktunya shalat dhuhur. Satu hari kerja dalam usahatani padi biasa disebut sabedug. Disebut sabedug karena berakhirnya jam kerja ditenggarai dengan bunyi bedug pertanda shalat dhuhur.
Upah untuk tenaga kerja wanita lebih murah daripada tenaga kerja pria. Hasil identifikasi di lokasi penelitian, upah tenaga buruh tani pria Rp50.000/HKP dan upah tenaga buruh tani wanita Rp30.000/HKW.

Tabel 6. Resume Estimasi NME dari Upah Buruh Tani Agregat

\begin{tabular}{cclrrr}
\hline No & URAIAN & SATUAN & \multicolumn{1}{l}{ AKTUAL } & PASCA REV & \multicolumn{1}{c}{ SELISIH } \\
1 & Luas Tanam & Ha/th & 1.500 & $2.120,55$ & 620,55 \\
2 & Tenaga Kerja & HKP & 120.000 & 169.644 & 49.644 \\
& & HKW & 60.000 & 84.822 & 24.822 \\
\multirow{2}{*}{3} & \multirow{2}{*}{ Upah Harian } & Rp/HKP & 50.000 & 50.000 & - \\
& & Rp/HKW & 30.000 & 30.000 & - \\
\multirow{2}{*}{4} & \multirow{2}{*}{ Agregat Upah } & HKP & 6.000 .000 .000 & 8.482 .200 .000 & 2.482 .200 .000 \\
& & HKW & 1.800 .000 .000 & 2.544 .660 .000 & 744.660 .000 \\
\hline \multicolumn{2}{c}{ NME dari upah buruh tani agregat } & 7.800 .000 .000 & 11.026 .860 .000 & 3.226 .860 .000 \\
\hline
\end{tabular}

Berdasarkan data pada Tabel 6 tersebut di atas, curahan tenaga kerja buruh tani pada kondisi aktual 12.000 HKP dan 60.000 HKP, pasca revitalisasi diprediksi akan meningkat menjadi 169.644 HKP dan 84.822 HKW. Apabila dinilai dengan uang curahan tenaga kerja aktual Rp7.800.000.000, diprediksi akan naik pasca revitalisasi irigasi menjadi Rp11.026.860.000. Nilai curahan tenaga kerja buruh tani pasca revitalisasi diprediksi akan naik sebesar Rp3.226.860.000. Artinya dengan revitalisasi irigasi akan meningkatkan potensi pendapatan untuk upah buruh tani yang tenaganya dicurahkan pada usahatani padi.

\section{Estimasi Nilai Manfaat Ekonomi dari Budidaya Perikanan}

Kolam ikan di lokasi penelitian jumlahnya cukup banyak. Hampir setiap rumah yang memiliki pekarangan, memiliki kolam, namun ukuran kolamnya kecil-kecil. Di lokasi penelitian diperkirakan terdapat 285 unit kolam, dengan ukuran sangat bervariasi berkisar antara (15-50) $\mathrm{m}^{2}$. Bandingkan misalnya dengan kondisi di kecamatan lain yang berbatasan dengan lokasi penelitian. Di Kecamatan Leuwisari, Sukaratu dan Cisayong, ada kolam ikan yang luasnya mencapai 0,5 hektar. Kondisi seperti ini tidak lepas dari karakteristik geografis Kecamatan Cigalontang merupakan wilayah perbukitan. Di lokasi penelitian tidak terlalu banyak hamparan lahan datar 
yang luas, sehingga menjadi kendala untuk membuat kolam berukuran luas. Budidaya ikan di kolam pada umumnya berorientasi subsisten, lebih mengutamakan untuk memenuhi kebutuhan keluarga dan kesenangan.

Budidaya ikan di kolam dapat dikatakan sebagai sampingan dari pemanfaatan kolam sebagai tempat mandi cuci dan kakus. Jenis ikan yang dibudidayakan petani cukup beragam seperti ikan nilem, tawes, mas, tambak, gurame, patin, bawal, lele dan berbagai jenis ikan lainnya. Diantara berbagai jenis ikan yang dibudidayakan, ikan mujaer merupakan jenis yang paling popular di budidayakan. Petani menanam berbagai jenis ikan dalam satu kolam (polikultur), memanfaatkan pakan yang diperoleh dari sisa makanan atau limbah rumah tangga.

Berdasarkan keragaan budidaya kolam ikan seperti yang telah diuraikan maka dapat disimpulkan bahwa keberadaan kolam di lokasi kajian tidak ditujukan untuk usaha perikanan. Fungsi utama kolam lebih diorientasikan sebagai tempat penampung air untuk aktivitas mandi cuci dan kakus, sementara budidaya perikanan hanya sebagai pemanfaatan sampingan, sehingga output ekonomi yang diperoleh kurang maksimal dibandingkan dengan potensinya. Dengan demikian dalam penelitian ini tidak dapat dihitung nilai manfaat ekonomi yang diperoleh dari budidaya perikanan.

Berkaitan dengan rencana revitalisasi jaringan irigasi, sekalipun debit air meningkat paca direvitalisasinya irigasi, diprediksi tidak akan menambah aktivitas budidaya usaha perikanan. Hal disebabkan karena dari aspek geografis tidak dimungkinkan adanya perluasan areal kolam. Di sisi lain budidaya kolam ikan di lokasi penelitian pada umumnya hanya sebagai pemanfaatan ruang penampungan air untuk kegiatan mandi cuci dan kakus.

\section{Estimasi Nilai Air Baku Untuk Rumah Tangga}

Sumberdaya air selain dimanfaatkan untuk pengairan lahan sawah dan budidaya perikanan air tawar, juga dimanfaatkan untuk keperluan air bersih rumah tangga penduduk. Pemanfaatan air oleh penduduk untuk memenuhi keperluan air bersih rumah tangga tidak lepas dari kondisi air. Menurut tokoh masyarakat setempat, pemanfaatan air irigasi cukup layak untuk keperluan memasak di dapur rumah tangga secara langsung, tanpa melalui treatment terlebih dahulu. Tampilan air pada saluran irigasi sangat jernih, sehingga pada kedalaman tertentu bisa tembus 
pandang sampai ke dasar saluran irigasi. Begitu jernihnya tampilan air, ikan yang berada di dasar saluran irigasi akan nampak kelihatan. Pemanfaatan sumber daya air untuk rumah tangga dilakukan secara individu dengan mengalirkan air ke kolam yang berada di halaman rumah. Ada pula yang membuat fasilitas MCK secara komunitas yang dimanfaatkan lima sampai sepuluh kepala keluarga.

Berdasarkan hasil identifikasi di lapangan, tidak kurang dari $950 \mathrm{KK}$ yang terdiri atas 2.850 penduduk setempat memanfaatkan air irigasi Cipangarangan untuk keperluan mandi, cuci dan kakus. Untuk keperluan valuasi ekonomi air yang manfaatkan untuk keperluan rumah tangga, penelitian ini merujuk referensi badan dunia UNESCO yang pada tahun 2002 menetapkan hak dasar manusia atas air yaitu sebesar 60 ltr/org/hari. Rujukan lainnya adalah Direktorat Jenderal Cipta Karya Departemen Pekerjaan Umum membagi standar kebutuhan air berdasarkan lokasi wilayah. Untuk wilayah Pedesaan kebutuhan 60 liter/per kapita/hari; Kota Kecil kebutuhan 90 liter/per kapita/hari; Kota Sedang dengan kebutuhan 110 liter/per kapita/hari; Kota Besar dengan kebutuhan 130 liter/per kapita/hari; Kota Metropolitan dengan kebutuhan 150 liter/per kapita/hari.
Berdasarkan rujukan klasifikasi standar kebutuhan air tersebut, kebutuhan air untuk di lokasi penelitian adalah termasuk klasifikasi lokasi pedesaan, sehingga untuk menghitung kebutuhan air penduduk di lokasi penelitian mengambil standar 60 liter/kapita per hari. Jumlah penduduk di Desa Puspamukti, Cigalontang dan Pusparaja yang memanfaatkan air irigasi Cipangarangan untuk keperluan domestik 2.850 jiwa.

Maka dapat dihitung air irigasi yang dimanfaatkan untuk keperluan domestik selama ini adalah adalah 171.000 liter per hari, setara dengan 62.415.000 liter per tahun. Untuk memenuhinya diperlukan debit air 1,98 liter/detik. Dengan asumsi harga air adalah sama dengan separuh dari tarif air yang berlaku di Perusahaan Daerah Air Minum Tirta Sukapura Kabupaten Tasikmalaya yaitu Rp1.650 untuk pemakaian per $10 \mathrm{~m}^{3}$ atau setara dengan Rp1,65/ liter. Maka nilai manfaat air yang digunakan untuk keperluan domestik adalah Rp102.984.750 per tahun. Rincian perhitungan nilai manfaat ekonomi dari air irigasi yang digunakan untuk keperluan rumah tangga dapat dilihat Tabel 7. 
Tabel 7. Nilai Manfaat Ekonomi Air untuk Keperluan Domestik

\begin{tabular}{cllrr}
\hline No & Uraian & Satuan & Nilai & $\begin{array}{r}\text { Keterangan } \\
\text { (Rujukan) }\end{array}$ \\
\hline A & Kebutuhan air perkapita/hari & Liter & 60 & Std PUPR \\
B & Jumlah penduduk & Jiwa & 2.850 & BPS 2019 \\
C & Kebutuhan air penduduk /hari & Liter & 171.000 & a x b \\
D & Kebutuhan air penduduk/tahun & Liter & 62.415 .000 & $\mathrm{c} \mathrm{x} \mathrm{365}$ \\
E & Tarif bersih air* & Rp /liter & 1,65 & SK Bupati \\
F & NME dari air domestik per tahun & Rp & 102.984 .750 & d x e \\
\hline Keterangan: * Tarif air PDAM Tirtasukapura untuk pemakaian rumah tangga (0-10) m3 adalah Rp 3.300
\end{tabular}

Pemanfaatan air irigasi untuk keperluan rumah tangga, mandi, cuci dan kakus terbatas pada penduduk yang memiliki akses, domisili mereka dekat dengan saluran irigasi. Sementara penduduk yang lainnya dalam memenuhi kebutuhan air bersih bersumber dari sumur gali. Pemanfaatan sumur gali dianggapnya lebih praktis dan murah dibandingkan dengan pemanfaatan sumber air irigasi yang harus memasang pipa. Kondisi seperti ini sekalipun debit air irigasi meningkat dengan adanya revitalisasi, pemanfaatan air untuk rumah tangga diprediksi tidak akan bertambah.

\section{Kesediaan Petani Membayar Jasa Layanan irigasi}

Pemanfaatan air untuk pertanian rakyat tidak termasuk dalam kategori yang dikenakan pajak ${ }^{1}$, namun demikian petani pemakai air tetap berkewajiban membayar iuran untuk pemeliharaan

\footnotetext{
1 UU No 28/2009. Ketentuan tersebut secara operasional diatur di tingkat menteri dengan Permen PUPR Nomor 15/2017. Peraturan Gubernur Jawa Barat Nomor 13 Tahun 2001,.
}

jaringan irigasi $^{2}$. Sebagian dari biaya pemeliharaan jaringan irigasi yang bersifat rutin merupakan tanggung jawab petani pengambil manfaat air. Hal demikian dimaksudkan agar jasa layanan irigasi berkesinambungan secara mandiri, tidak secara terus menerus tergantung pada pembiayaan dari pemerintah.

Berkaitan dengan adanya usulan untuk merevitalisasi jaringan irigasi, berapa besar iuran yang harus dibayar petani untuk pemeliharaan jaringan irigasi pasca dilakukannya revitalisasi. Besarnya iuran selayaknya ditentukan atas dasar kesepakatan yang ditetapkan dalam musyawarah petani pemakai air. Jangkauan kemampuan dan keinginan (ATP dan WTP) selayaknya menjadi dasar pertimbangan utama dalam penetapan besarnya iuran yang harus ditanggung oleh petani. ATP, merupakan cerminan keterjangkauan (daya beli) petani terhadap jasa layanan irigasi. Sementara WTP merupakan cerminan

\footnotetext{
2 Pengguna jaringan irigasi turut serta dalam pembiayaan pengelolaan jaringan irigasi yang dibangun oleh Pemerintah Daerah. (Pasal 30 ayat 5 Pergub Jabar Nomor 4 Tahun 2008).
} 
keberanian petani untuk membayar atas dasar tingkat kepuasan layanan yang diperolehnya.

\section{Kemampuan Petani Membayar (Ability to pay, ATP)}

Kemampuan jangkauan petani membayar iuran jasa layanan irigasi berhubungan dengan besarnya pendapatan usahatani dari pemanfaatan air pada jaringan irigasi tersebut. Petani yang berlahan luas memiliki pendapatan yang relatif lebih besar dibandingkan dengan pendapatan petani yang berlahan sempit. Pada gilirannya petani yang berlahan luas berpendapatan besar cenderung memiliki kemampuan membayar yang lebih besar dibandingkan dengan petani yang berlahan sempit berpendapatan relatif kecil.

Semakin luas lahan usahatani yang dikelola, semakin banyak menggunakan air irigasi, diharapkan volume produksi usahataninya besar sehingga semakin besar ATP-nya, sebaliknya petani yang mengelola usahatani dengan lahan yang sempit ATP-nya cenderung kecil.

Berdasarkan hasil identifikasi di lapangan, petani pemakai air dengan luas lahan berkategori paling sempit $(0,01$ $0,41)$ hektar, rata-rata ability to pay-nya 4 kg GKP per musim. Sedangkan petani dengan kategori satuan lahan usahatani terluas $(1,61-2,01)$ hektar ability to paynya $37,1 \mathrm{~kg}$ GKP per musim tanam.

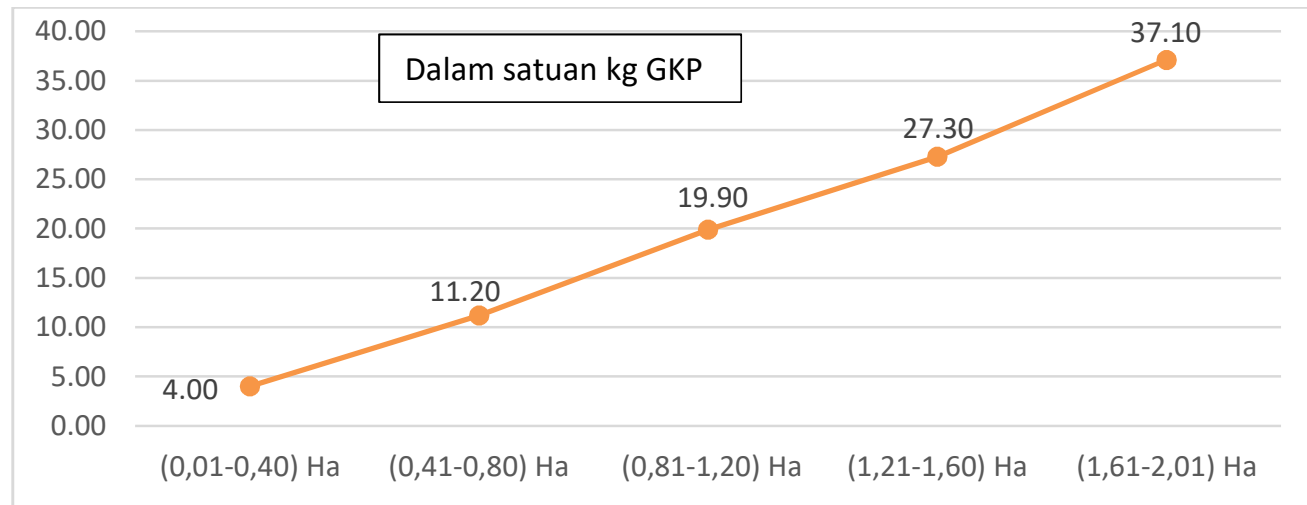

Gambar 1. Kurva ATP berdasarkan Segmentasi Luas Lahan Usaha Tani

Jumlah petani pemakai air irigasi semakin menurun proporsinya seiring dengan semakin besarnya ATP-nya. Proporsi jumlah petani mencapai 59,3\% untuk nilai ATP 4,0 kg GKP. Proporsi tersebut hanya mencapai $2,2 \%$ untuk nilai ATP sebesar 37,1 kg GKP. Proporsi jumlah petani berdasarkan besaran nilai ATP-nya secara rinci dapat dilihat Gambar 2. 


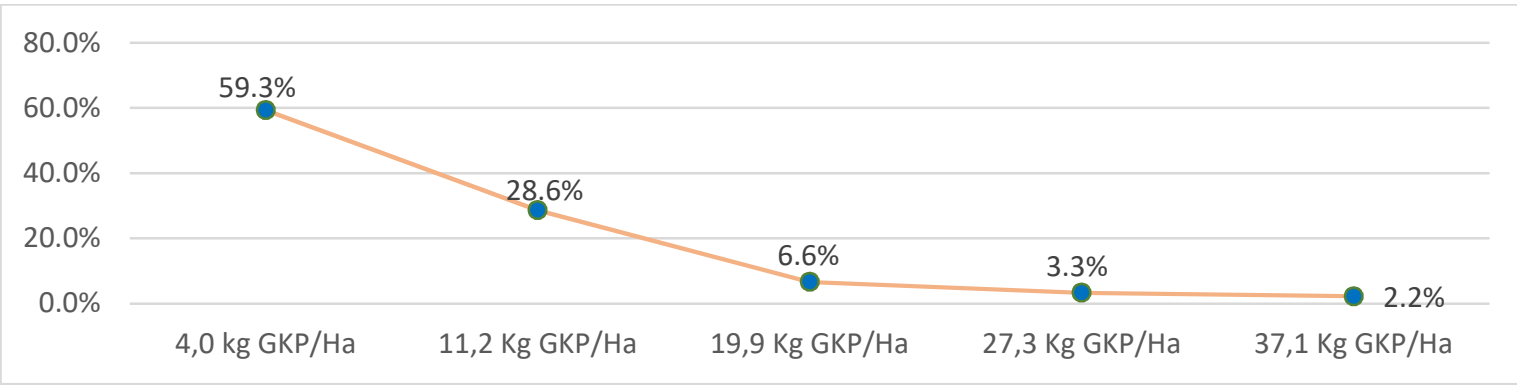

Gambar 2. Proporsi Jumlah Petani berdasarkan Besarnya ATP

Proporsi jumlah petani pada setiap segmen ATP, dapat digunakan untuk estimasi jumlah petani untuk setiap segmen ATP pada populasi. Proporsi jumlah petani dengan ATP rata-rata terendah, yaitu $4 \mathrm{~kg}$ per musim adalah 59,3\%, maka dapat diestimasi jumlah petani dari populasi 956 orang, yang bersedia membayar jasa layanan irigasi dengan nominal $4 \mathrm{~kg}$ per musim adalah 567 orang. Proporsi jumlah petani dengan segmentasi $A T P$ terbesar yaitu $37,1 \mathrm{~kg}$ per musim adalah $2,2 \%$, yaitu setara dengan 21 orang. Total ATP dari petani yang luas lahannya pada kategori tersempit (0,01-40) Ha adalah $2.268 \mathrm{~kg}$ GKP setara Rp 10.206.000 (Harga gabah di lokasi saat penelitian Rp 4.500/kg) dan total ATP dari petani yang luas lahannya berada pada kategori paling luas $(1,61-$ 2,01) Ha adalah $779 \mathrm{~kg}$ GKP atau setara Rp3.505.950. Harga gabah pada saat penelitian adalah Rp4.500/kg, maka rincian total nilai ATP dalam satuan rupiah berdasarkan segmentasi luas lahan usahatani disajikan dalam bentuk ilustrasi grafis dapat Gambar 3.

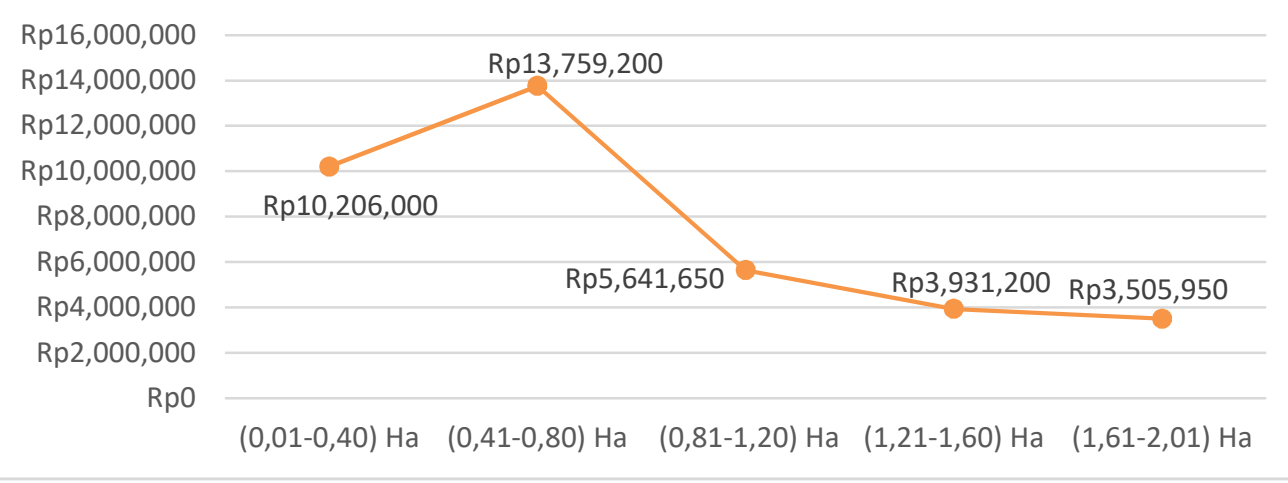

Gambar 3. Kurva ATP Total berdasarkan Segmentasi Luas Usahatani

Berdasarkan rincian besarnya ATP total pada setiap segmentasi luas lahan usahatani yang dikuasai petani seperti yang tergambarkan dalam ilustrasi grafis Gambar 6.4 tersebut dapat dihitung ATP total untuk seluruh populasi petani 
pemakai air irigasi Cipangarangan, adalah $8.232 \mathrm{~kg}$ GKP atau setara dengan Rp 37.044.000 per musim tanam. Dibandingkan dengan tidak diberlakukan iuran sama sekali, sesungguhnya petani pemakai air memiliki potensi cukup besar untuk membayar iuran berdasarkan jangkauan kemampuannya. Potensi sumber keuangan yang berasal dari pemakai air untuk pemeliharaan jaringan irigasi bisa diberdayakan untuk lebih meningkatkan layanan yang lebih baik.

\section{Keinginan Petani Membayar (WTP)}

Berdasarkan hasil identifikasi di lapangan keinginan membayar (WTP) petani pemakai jasa layanan irigasi, memiliki korelasi negative dengan besaran harga yang ditawarkan, melalui bidding system. Semakin besar nilai nominal jasa layanan irigasi yang ditawarkan semakin kecil proporsi jumlah petani yang berkeinginan membayar. Dengan kata lain semakin kecil nilai nominal jasa layanan irigasi yang ditawarkan semakin besar proporsi petani yang bersedia membayar. Besarnya harga lelang dalam bidding system jasa layanan irigasi yang ditawarkan merujuk pada rata-rata besarnya iuran yang berlaku di Pantura Jabar, berkisar antara (15-25) kg GKP per hektar per musim. Untuk keperluan analisis dalam lima skala ukur, interval harga lelang diperlebar sehingga dalam simulasi bidding system dimulai dengan $10 \mathrm{~kg}$ GKP dan berakhir pada penawaran harga $30 \mathrm{~kg}$ GKP.

Pada saat harga jasa layanan irigasi yang ditawarkan sebesar $10 \mathrm{~kg}$ GKP setara Rp45.000 per hektar per musim tanam, proporsi jumlah petani yang menyatakan keinginan membayar 47,3\%. Proporsi tersebut turun menjadi 19,8\% pada saat harga yang ditawarkan dinaikan menjadi $15 \mathrm{~kg}$ GKP atau setara dengan Rp67.500. Pada harga tertinggi yang ditawarkan kepada responden untuk jasa layanan pemanfaatan air irigasi adalah 30 $\mathrm{kg}$ GKP per hektar permusim tanam setara dengan Rp135.000, proporsi jumlah petani yang bersedia membayar $7,7 \%$.

Kondisi tersebut merupakan gambaran logis, sesuai dengan hukum permintaan dalam ilmu ekonomi. Harga suatu produk memiliki korelasi positif dengan kuantitas penawaran produk tersebut, namun memiliki korelasi negative dengan volume permintaannya (Nuraini, 2018). Pada saat harga jasa layanan irigasi yang ditawarkan rendah, proporsi jumlah petani pemakai air yang berkeinginan membayarnya besar. Sebaliknya, pada saat jasa layanan irigasi harganya dinaikan secara bertahap, maka 
proporsi jumlah petani yang menyatakan keinginannya untuk membayarnya secara bertahap berangsur semakin menurun.
Gambar 4 berikut ini menunjukkan proporsi jumlah petani untuk setiap besaran iuran yang ditawarkan.

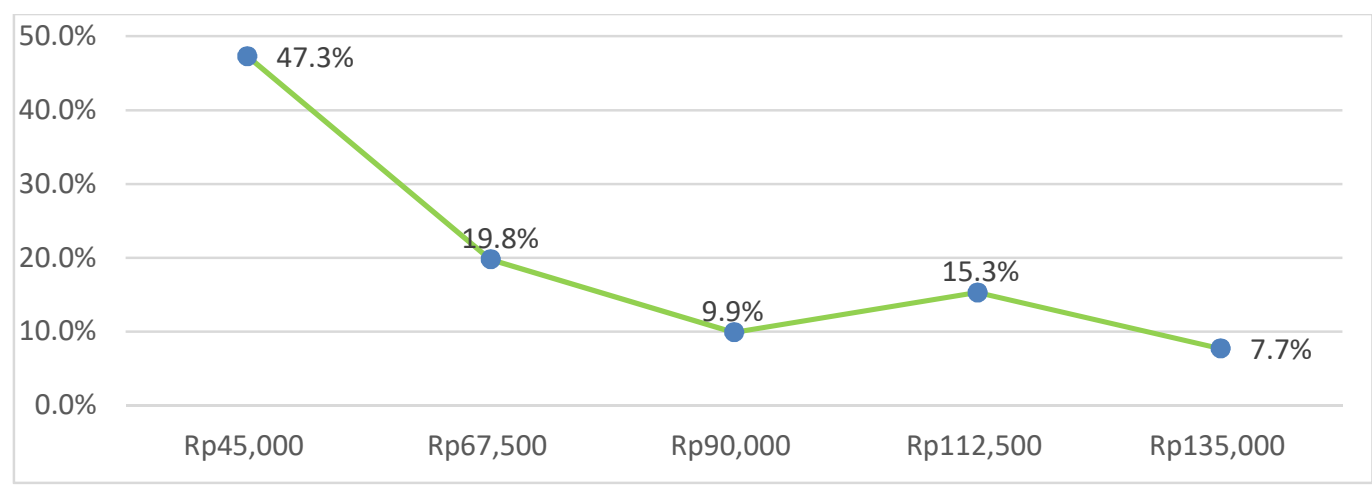

Gambar 4. Kurva Proporsi Jumlah Petani Berdasarkan besarnya WTP

Berdasarkan proporsi jumlah petani pada setiap harga yang ditawarkan melalui sampel, dapat diprediksi jumlah petani yang berkeinginan membayar (WTP) pada setiap tingkatan harga pada populasi. Pada saat harga terendah yang ditawarkan untuk jasa layanan irigasi yang ditawarkan yaitu $10 \mathrm{~kg}$ GKP untuk satu musim tanam per hektar proporsi jumlah petani pemakai air yang berkeinginan membayar $47,3 \%$, sehingga dapat diestimasi jumlah petani pada populasi yang berkeinginan membayar (WTP) adalah 452 Orang. Sementara pada saat harga tertinggi yang ditawarkan yaitu $30 \mathrm{~kg}$ GKP proporsi jumlah petani yang berkeinginan membayar menurun menjadi 7,7\%, sehingga jumlah petani pada populasi diestimasi 74 orang.

Tabel 8. Estimasi Jumlah Petani yang Berkeinginan Membayar pada Setiap Tingkatan Besarnya Iuran Jasa Layanan Irigasi yang Ditawarkan

\begin{tabular}{ccccc}
\hline No & Besaran Harga (kg) GKP & Proporsi & Jumlah Petani (orang) & Total WTP (kg) GKP \\
\hline 1 & & & 452 & 4.520 \\
2 & 10 & $47,3 \%$ & 189 & 2.835 \\
3 & 15 & $19,8 \%$ & 95 & 1.900 \\
4 & 20 & $9,9 \%$ & 146 & 3.650 \\
5 & 25 & $15,3 \%$ & 74 & 2.220 \\
\hline Jumlah & 30 & $7,7 \%$ & 956 & 15.125 \\
\hline
\end{tabular}

Pada saat besaran nilai iuran terkecil untuk jasa layanan irigasi yang ditawarkan sebesar $10 \mathrm{~kg}$ GKP jumlah petani yang berkeinginan membayar
(WTP) adalah 452, sehingga total WTP pada segmentasi $10 \mathrm{~kg}$ adalah $4.520 \mathrm{~kg}$. Dengan asumsi harga gabah kering pungut $\mathrm{Rp} 4.500 / \mathrm{kg}$, maka total nilai WTP 
pada segmentasi harga tersebut setara dengan Rp20.340.000. Pada saat harga jasa layanan irigasi yang tertinggi ditawarkan, yaitu sebesar $30 \mathrm{~kg}$ GKP per hektar per musim, jumlah petani yang berkeinginan membayar $7,7 \%$. Hal ini berarti, jumlah populasi petani yang berkeinginan membayar adalah 74 orang. Maka total WTP pada segmen harga tertinggi adalah $2.220 \mathrm{~kg}$ GKP atau setara dengan Rp 9.990.000 per hektar per musim.
Berdasarkan rincian besarnya WTP total pada setiap segmentasi harga yang ditawarkan seperti yang tergambarkan dalam ilustrasi grafis Gambar 5 tersebut dapat dihitung WTP total untuk seluruh petani pemakai air irigasi Cipangarangan, yaitu Rp68.062.500 per musim tanam. Rincian total WTP setiap segmentasi harga yang ditawarkan dapat dilihat ilustrasi grafis pada Gambar 5.

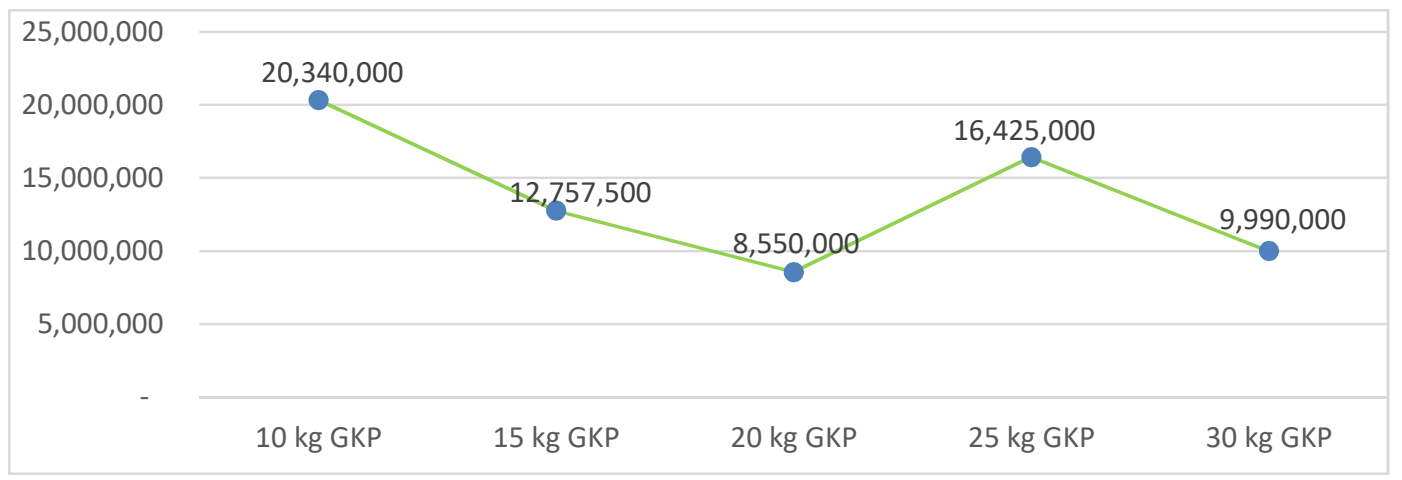

Gambar 5. Total WTP pada setiap segmen tarif iuran yang ditawarkan

\section{Komparasi ATP dengan WTP}

Berdasarkan hasil pembahasan kesediaan membayar tersebut di atas, total nilai $A T P$ untuk jasa layanan irigasi Rp37.044.000 per musim tanam, relatif lebih kecil dibandingkan dengan nilai WTP total Rp68.062.500. Apabila nilai tersebut dibandingkan dengan jumlah populasi, dapat dihitung average ability to pay (EATP) adalah Rp38.749 dan nilai average willingness to pay (EWTP) adalah Rp. 71.195. Keadaan ini tersebut dapat disimpulkan jangkauan kemampuan petani untuk membayar lebih kecil dari keinginan untuk membayar jasa layanan irigasi (ATP < WTP). Rata-rata petani mau membayar jasa layanan irigasi untuk nominal yang lebih tinggi dari jangkauan kemampuannya.

Kondisi seperti ini menggambarkan utilitas jasa irigasi relatif lebih tinggi daripada penghasilan pengguna jasa. Kondisi seperti ini disebut Captive riders. Hal ini dapat diartikan rata-rata petani 
pemakai air memiliki semangat dan komitmen membayar jasa layanan irigasi yang begitu besar dibandingkan dengan kemampuan membayarnya. Kondisi tersebut terutama tergambarkan pada petani yang memiliki lahan yang relatif luas $(\geq 0,081)$ hektar. Sementara petani yang berlahan relative sempit cenderung pesimis, sehingga WTP-nya relatif lebih kecil dari ATP-nya. Petani berlahan sempit kurang ada keberanian atau keinginan untuk membayar jasa layanan irigasi dibandingkan dengan petani yang berlahan luas.

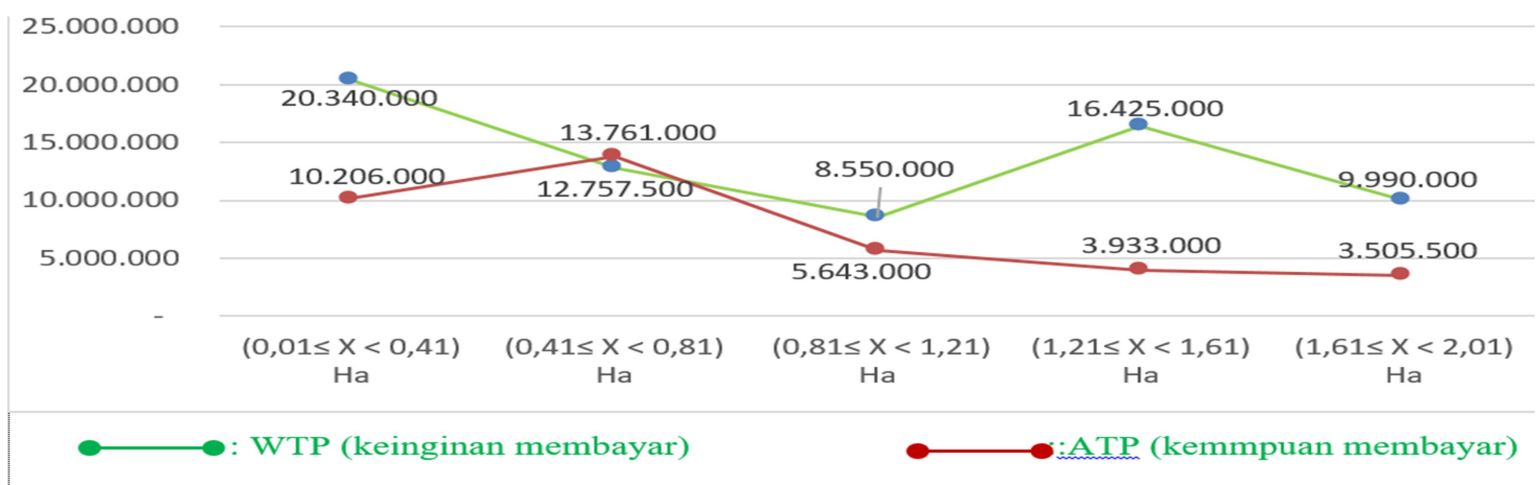

Gambar 6. Ilustrasi Grafis Komparasi Nilai ATP dengan WTP

\section{KESIMPULAN DAN SARAN}

1. Revitalisasi irigasi Cipangarangan diprediksi dapat meningkatkan nilai manfaat ekonomi (NME) sebesar Rp10.934.091.000 per tahun. Nilai sebesar itu terdiri atas estimasi peningkatan pendapatan bersih usahatani padi sebesar Rp7.707.231.000 dan peningkatan serapan tenaga kerja buruh tani 49.644 HKP dan 24.822 HKW, setara dengan Rp3.226.860.000 per tahun. Sementara dari budidaya perikanan air tawar dan pemanfaatan air untuk keperluan domestik diprediksi tidak mengalami perubahan, sekalipun terjadi peningkatan debit air irigasi.
2. Rata-rata ATP untuk jasa layanan irigasi relative lebih kecil (Rp38.749) jika dibandingkan dengan rata-rata WTP (Rp71.195). Kondisi ini menunjukan jangkauan kemampuan petani untuk membayar jasa layanan irigasi lebih kecil dari keinginannya untuk membayar (ATP $<$ WTP). Kondisi seperti ini menggambarkan keberanian petani untuk membayar jasa layanan irigasi melebihi jangkauan kemampuannya, utilitas jasa irigasi relatif lebih tinggi daripada pendapatan pengguna jasa. Kondisi seperti ini disebut Captive riders. 
Beberapa saran untuk pemerintah daerah, perkumpulan petani pemakai air jaringan irigasi Cipangarangan:

1. Pemerintah Kabupaten Tasikmalaya dapatlah kiranya mempertimbangkan usulan revitalisasi irigasi Cipangarangan menjadi salah satu bagian dari urutan prioritas agenda pembangunan. Hasil penelitian ini dapat menjadi salah satu referensi dalam penyusunan Feasibility Study dan Detil Desain revitalisasi irigasi yang diusulkan ppemakai air.

2. Untuk menjaga kesinambungan jasa layanan irigasi, selayaknya diberlakukan iuran bagi pengguna air. Penetapan besarnya iuran, sebaiknya mempertimbangkan keragaman karakteristik petani pemakai air, ATP dan WTP sehingga ada keselarasan penetapan besarnya iuran dengan keinginan dan jangkauan kesanggupan membayar dari petani.

3. Penetapan nominal besaran iuran jasa layanan irigasi disarankan setinggitingginya sama dengan nilai ATP. Apabila terpaksa harus menetapkan besaran iuran di atas nilai ATP, maka sebaiknya masih di bawah nilai WTP.

4. Penetapan tarif iuran air di atas nilai ATP harus disertai dengan subsidi dari pemerintah (daerah) sebesar selisih besaran tarif iuran dengan
ATP.

5. Penetapan besarnya iuran di atas WTP sebaiknya tidak dilakukan karena selain berada di luar jangkauan kemampuan, juga berada dalam posisi yang tidak dikehendaki oleh petani pemakai air.

\section{DAFTAR PUSTAKA}

Akhmad Fauzi, P. 2006. Ekonomi Sumber Daya Alam dan Lingkungan Teori dan Aplikasi. PT Gramedia Pustakan Utama. Jakarta. Creswell John. 2010. Research Design Pendekatan Kualitatif,Kuantitatif dan Mixed. Pustaka Pelajar. Yogyakarta.

Dinas Sumber Daya Air Provinsi Jawa Barat 2017. Servey dan Pemetaan Air Baku di Kabupaten Tasikmalaya. Bidang Perencanaan Teknik. Dinas Sumber Daya Air Provinsi Jawa Barat. Bandung.

Fadillah. 2014. Pendapatan dan Kesejahteraan Rumah Tangga Nelayan Obor di Kota Bandar Lampung. Jurnal JIIA. Vol 2. No 1. Diakses 10 Desember 2020

Gilarso.T. 2003. Pengantar Ilmu Ekonomi Mikro. Penerbit Kanisius. Jakarta.

Guntoro, F. P. (2003). Analisis Model Kemauan Dan Kemampuan Bayar Petani Atas Iuran Pelayanan Air Irigasi (Studi Kasus Daerah Irigasi Sidorejo Kabupaten Grobogan). Program Pascasarjana Universitas Diponegoro. Semarang. Diakses 12 Desember 2020.

Hendri. 2012. Menentukan Ukuran Sampel Menurut Para Akhli. Litelature Review And Research Paper dalam https://teorionlinejurnal.wordpress. com/2012 /08/20/ menentukan- 
ukuran-sampel-menurut-para-ahli/. Diakses 26 September 2020

I Gusti Ayu Manuati Dewi. 2015. Pengaruh Pendapatan Pada Konsumsi di Indonesia Pengembangan Model Teoritis dan Pemilihan Model Empiris https://www.google.com/search. Dikases 28 September 2020.

Irawan, B. 2009. Willingness To Pay Dan Ability To Pay Pelanggan Rumah Tangga Sebagai Respon Terhadap Pelayanan Air Bersih Dari PDAM Kota Surakarta. JEJAK Volume 2 No. 1.Diakses 25 September 2020.

James C. Scott. 1981. Moral ekonomi petani : pergolakan dan subsistensi di Asia Tenggara =The Moral economy of the peasant: rebellion and subsistence in Southeast Asia/penerjemah, Hasan Basri; penyunting, Bur Rasuanto. LP3S. Jakarta.

Kunu. JP. 2013. Mitigasi Krisis Air Dan In-Effisiensi Pemanfaatan Air Di Pulau-Pulau Kecil. Diakses 28 Desember 2020

Kotler, Philip dan Gary Armstrong. 2008. Prinsip-prinsip Pemasaran. Diterjemahkan oleh Bob Sabran M.M. Edisi Kedua Belas. Jilid 1. Erlangga. Jakarta:

Linda Laila Zahasfana, E Bagus Kuntadi dan J. M Mulyo Aji (2017) Curahan Tenaga Kerja Pada Usahatani Padi Di Desa Gumelar Kecamatan Balung Kabupaten Jember. Volume 01, No 02September 2017 ISSN: 2581-1339. Diakses 28 Desember 2020

M. Yanuar J. Purwanto dan Agus Susanto. 2016. Dasar dan Perkembangan Pengelolaan Sumberdaya Air di Indonesia.

Panguriseng. 2019. Pemanfaatan Sumber Daya Air Berkelanjutan \& Permasalahannya (Keynote Speaker) Makalah pada International Seminar Civil in
Progressive 2019, Universitas Muhammadiyah Makasar. Diakses 10 Agustus 2020.

Peraturan Pemerintah Nomor 20 Tahun 2006 Tentang Irigasi maupun Peraturan Pemerintah Nomor 42 Tahun 2008 Tentang Pengelolaan Sumber Daya

Permata, M. R. 2012. Analisa Ability To Pay dan Willingness To Pay Pengguna Jasa Kereta Api Bandara Soekarno Hatta Manggarai. Depok: Program Studi Teknik Sipil Universitas Indonesia. Diakses 20 Agustus 2020.

Prabowo, A., \& Wiyono J. (2006). Pengelolaan sistem irigasi mikro untuk tanaman hortikultura dan palawija. Agricultural Engineering. Jurnal Irigasi - Vol. 11, No. 1,Mei 2016 ,

Sadono Sukirno 2006. Teori Mikroekonomi Suatu Pengantar. PT. Raja Grafindo Jakarta.

Said Rusli. 2005. Pengantar Ilmu Kependudukan . Jakarta

Sajogyo. 1977. Golongan Miskin dan Partisipasi dalam Pembangunan (Poor Household and Their Participation in Development). Prisma, VI(3):10 -17. Diakses 20 September 2020.

Sajogyo dan Pudjiwati Sajogyo. 1990. Sosiologi Pedesaan. Yogyakarta: Gadjah Mada University Press.

Sintala Arsyad dan Ernan Rustiadi 2012. Efisensi Penggunaan Sumber daya air: Suatu Tinjauan dari sisi Agroklimat dan Hdrologi. Penyelamatan Tanah, Air dan Lingkungan. Yayasan Obor Indonesia. ISBN 978. 979. 461.702-1

Soekartawi. 2002 Analisis Usahatani, Universitas Indonesia. Jakarta.

Soekartawi. 2007. Teori Ekonomi Produksi Analisis Fungsi CobbDouglas. Rajawali Pers. Jakarta. 
Soewarno. 2000. Hidrologi Operasional Jilid Kesatu. PT.Citra Aditya Bakhti.Bandung. ISBN: 979-414833-4

Sugiyono. (2017). Metode Penelitian Kuantitatif, Kualitatif, dan R\&D. Alfabeta, Bandung.

Suharsimi Arikunto. 2005. Manajemen Penelitian. Rineka Cipta. Jakarta.

Sumaryanto. (2006). Iuran Irigasi Berbasisi Komoditas Sebagai Instrumen Peningkatan Efesiensi Penggunaan Air Irigasi: Pendekatan Dan Analisis FaktorFaktor Yang Mempengaruhi Implementasinya. Bogor: Sekolah Pascasarjana Institut Pertanian Bogor.

Susilowati, S.H (2016). Fenomena penuaan petani dan berkurangnya tenaga kerja muda serta implikasinya bagi kebijakan pembangunan pertanian. Jurnal Forum Penelitian Agro Ekonomi Vol 34 No. 1 Juli 2016. Diakses 18 Desember 2020.

Susilowati, S.H. dan Mohamad Maulana (2011). Luas Lahan Usahatani dan Kesejahteraan Petani : Eksistensi Petani Gurem dan Urgensi Kebijakan Reforma Agraria. Pusat Sosial Ekonomi dan Kebijakan Pertanian. Diakses 18 Desember 2020.

Suprianto dan Eri Cahrial (2016). Kajian Alih Fungsi Lahan Pertanian Pangan Di Kota Tasikmalaya. Mimbar Agribisnis. Vol 1 Nomor 3 Tahun 2016. Diakses 2 Desember 2020
Trifly Kawengian Juliana Ruth Mandey Nordy Fritsgerald Lucky Waney. (2019). Curahan Tenaga Kerja Pada Usahatani Padi Di Desa Lowian Kecamatan Maesaan. AgriSosioEkonomi Unsrat, ISSN (p) 1907-4298, ISSN (e) 2685-063X, Terakreditasi Jurnal Nasional Sinta 5, Volume 15 Nomor 3, September 2019 : 397- 406. Diakses 28 Desember 2020.

Walhi, 2007. Adakah yang tahu sekarang hari air https://walhijabar.wordpress. com /2007/12/26/adakah-yang-tahusekarang-hari-air/ diakses 28 Agustus 2020.

Whitehead, John C. 2005. Combining Willingness to Pay and Behavior Data with Limited Information. Resource and Energy Economics, Vol.27, No.2, http://libres.uncg.edu/ir/asu/f/White head_John_2005_Combining_Willi ngness.pdf. Diakses pada tanggal 10 Oktober 2020.

Wirawan. 1991. Pengembangan dan Pemanfaatan Lahan Sawah Irigasi. dalam E. Pasandaran (edt). Irigasi di Indonesia Strategi dan Pengembangan. LP3ES. Jakarta. 